Proceedings

\title{
A Study of Parastes of Three Imported Ornamental Fishes Conducted in Limpopo Province, South Africa ${ }^{\dagger}$
}

\author{
Linda Prince Lukhele
}

Citation: Lukhele, L.P. A Study of Parastes of Three Imported Ornamental Fishes Conducted in Limpopo Province, South Africa. Proceedings 2021, 68, $\mathrm{x}$ https://doi.org/10.3390/xxxxx

Published: date

Publisher's Note: MDPI stays neutral with regard to jurisdictional claims in published maps and institutional affiliations.

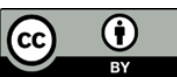

Copyright: (C) 2021 by the authors Submitted for possible open access publication under the terms and conditions of the Creative Commons Attribution (CC BY) license (http://creativecommons.org/licenses /by/4.0/).

\begin{abstract}
The Department of Biodiversity, School of Molecular and Life Sciences, Faculty of Science and Agriculture, University of Limpopo, South Africa; e-mail@e-mail.com

+ Presented at the 1st International Electronic Conference on Biological Diversity, Ecology and Evolution, 1531 March 2021; Available online: https://bdee2021.sciforum.net/.
\end{abstract}

\begin{abstract}
Invasive alien species pose a significant threat to biodiversity in the area where they have been introduced. In South Africa, most of ornamental fishes sold are imported from other countries. The parasites of alien species can be transported along with their hosts and become co-invasive. An invasive parasite from Asia, Camallanus cotti was reported in Africa for the first time in the year 2017 from the guppy, an ornamental fish which established a feral population. This is proof that ornamental fish may introduce alien parasites. Three ornamental fish species were imported (Red rainbowfish, pearl gourami and clown loach) from Indonesia. Standard methods were used for the dissection of fish, examination, fixation and preservation of parasites. The prevalence and mean intensity of different parasites of each fish species were determined and they were identified to genus and species level where possible. Nematodes (Camallanus cotti and Procamallanus sp), cestodes (Neogryporhynchus cheilancristrotus and Dendrouterina herodiae), a copepod (Lernaea cyprinacea) and monogeneans were found from the imported fishes. Two new species of monogeneans (here named Ancyrocephalidae sp. 1 and Ancyrocephalidae sp. 2) not belonging to any established genus were discovered. Cestodes were only found from pearl gourami and the copepod from red rainbowfish. The clown loach had no parasites. Red rainbowfish had the highest prevalence and mean intensity for mongeneans and nematodes.
\end{abstract}

Keywords: Ornamental fishes; alien species; parasite; new species; South Africa

\section{Introduction}

\subsection{Background Information}

Invasive alien species pose a significant threat to biodiversity in the area where they have been introduced (Goyal 2005). There's international trading of above a billion ornamental fish consisting of more than 4000 freshwater and 1400 marine species each year (Whittington and Chong 2007). In a review by Ellender and Weyl (2014) on non-native freshwater fish introductions in South Africa, a list was established whereby there was a total of 55 fishes that have been introduced into new environments in South Africa, with 27 of those being alien. Ellender and Weyl (2014) also emphasised that the co-introduction of parasites is a serious threat to native fish communities in South Africa. Introduction of these parasites (through trading of ornamental fish) may lead to a decrease in native fish diversity in South Africa, possibly through eventual extinction of native fish species.

Translocation of freshwater fish into non-native regions affects the native life found there (Smith et al. 2017) and the trading of ornamental fish species is considered to be an important pathway through which alien parasites can be introduced to native fish species (Gozlan et al. 2010). According to Bruton and Van As (1986), "The major vectors for introductions of non-native fishes in South Africa were primarily associated with recreational 
angling, aquaculture, conservation translocations, ornamental fish trade, inter-basin water transfer schemes (IBTs) and bio-control". There are other factors that lead to the introduction of non-native fish species (and with them their parasites) in South Africa, with ornamental fish trading being one of the main factors.

\subsection{Purpose of Study}

\subsubsection{Problem Statement}

Invasive alien species are recognised as one of the main factors threating native species worldwide (Kathiresan et al. 2005). In South Africa, most of ornamental fishes sold are imported from other countries (Mount et al. 2001). This means that South Africa receive alien species from different countries, which may be a threat to South Africa's native fish species when released into nature. The parasites of alien species can be transported along with their hosts and become co-invasive (Lymbery et al. 2014). An invasive parasite from Asia, Camallanus cotti Fujita 1927 was reported in Africa for the first time in the year 2017 from an ornamental fish, Poecillia reticulata Peters, 1859 collected from Komati River and from several pet shops in South Africa (Tavakol et al. 2017). It is thus evident that ornamental fish may introduce alien parasites. The potential impacts of parasites switching from the host they were introduced with to a new native host have been well documented (Adlard et al. 2015). In South Africa there are a limited number of studies done on ornamental fish parasites (Mount et al. 2001, Tavakol et al. 2017), therefore the assumption that importing ornamental fishes from different countries brings along with their parasites needs more studies to be substantiated.

\subsubsection{Aim}

The aim of the project was to study the parasite diversity of three ornamental fish species bought from importers to South Africa.

\subsubsection{Objectives}

The objectives of the study were to:

i. determine the prevalence and mean intensity of different parasites of each fish species examined

ii. identify the parasites to genus level and where possible to species level

\section{Material and Methods}

\subsection{Sampling of Fish}

The fishes were obtained using a well-established importing company, WCB Imports, Midrand. Fish species were selected from the supplier's list and the following species from the Aquazone in Indonesia were received: Red rainbowfish, Glossolepis incisus Weber, 1907; pearl gourami, Trichopodus leerii (Bleeker, 1852) and clown loach, Chromobotia macracanthus (Bleeker, 1852). Due to the fact that we needed to examine the fish before they receive any treatment for parasites or diseases, the fishes were collected directly at the OR Tambo International Airport, Johannesburg upon the cargo aircraft landing. A number of 21 red rainbowfish, 15 pearl gourami and 15 clown loaches were received in the middle of October 2020.

\section{Fish Hosts.}

Glossolepsis incisus is known as red rainbowfish and belonging to Melanotaeniidae family. It is endemic to Indonesia's lake, Sentani in Irian Jaya (Siby et al. 2017). It is the "Type species" for the genus Glossolepsis with currently nine species (Eschmeyer et al. 2012). It is characterised by bright colours and small body size (Alien 1980). It takes between 5 and 7 days for their eggs to hatch (Kadarini et al. 2013). It can survive a pH range 
of 7.6-8.2 and temperatures between 29 and 30 degree Celsius (Allen 1991). They can grow to a maximum length of $12 \mathrm{~cm}$ (Allen 1991).

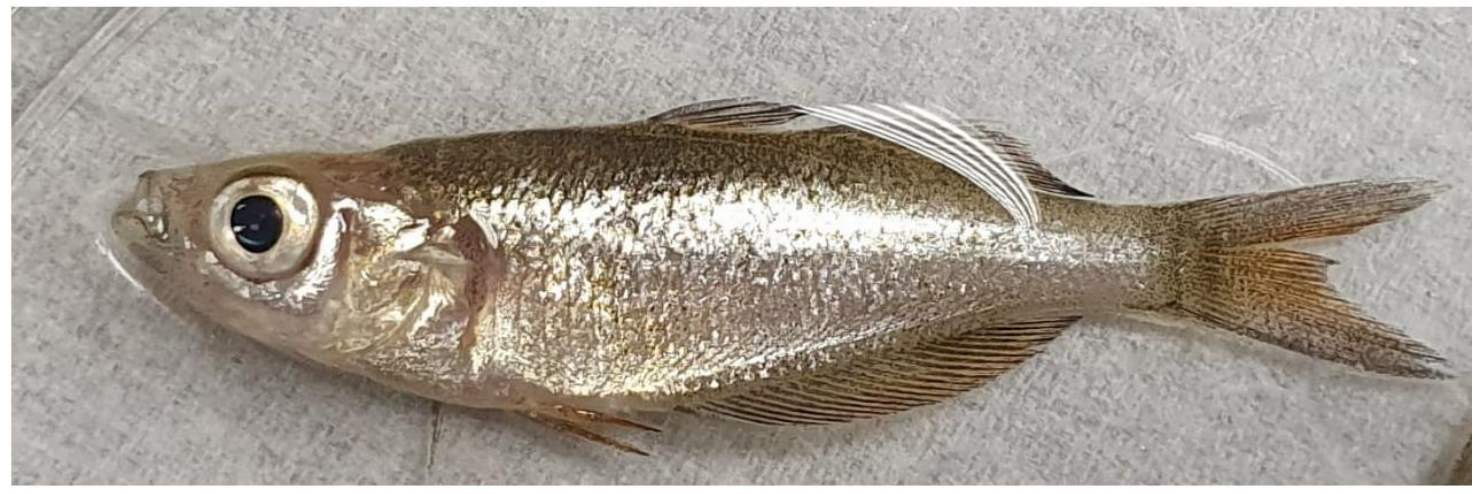

Figure 1. Glossolepsis incisus.

Chromobotia macranthus, known as clown loach, belongs to the family Botiidae, and is the only member of the genus Chromobotia. The clown loach is endemic to Indonesia in the rivers of the islands Borneo and Sumatra (Kottelat et al. 1995) and it is considered as a major species on international market of ornamental freshwater fish (Legendre et al. 2012). It is characterised by attractive colour patterns, with three wide bars running across their orange-reddish body. They can grow to a maximum length of $30.5 \mathrm{~cm}$ and commence their breeding at the beginning of rainy seasons in fast flowing streams (Kottelat 2004; Legendre et al. 2012).

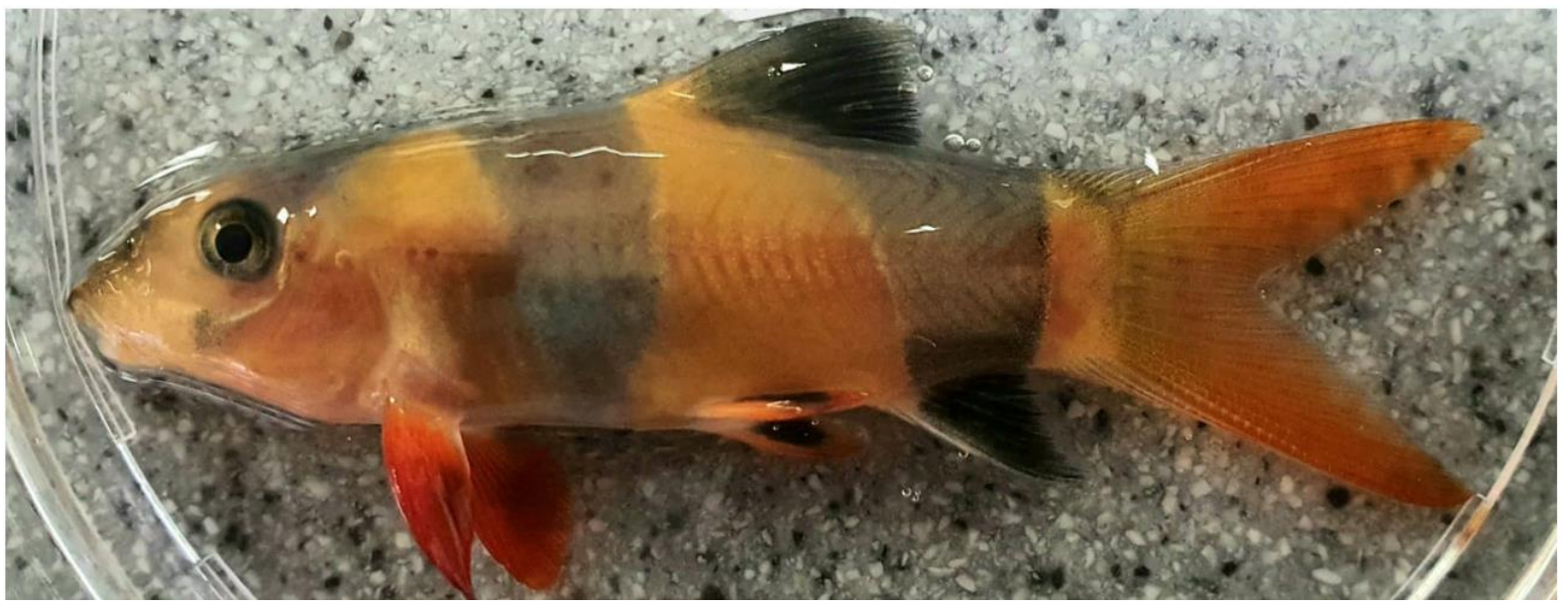

Figure 2. Chromobotia macracanthus.

Trichopodus leeri, commonly known as pearl gourami, belongs to the family Osphronemidae and it is native to Southeast Asia (Roberts 1989). Pearl gouramis are air breathing and directly undergo gas exchange with the atmosphere (Graham 2005). Its accessory air breathing organs include the skin, gas bladder and the digestive tract (Huang et al. 2008). They can grow to a maximum length of $12 \mathrm{~cm}$ and can survive temperatures between 24 and 28 degrees Celsius and a pH between 6 and 8 (Roberts 1989). 


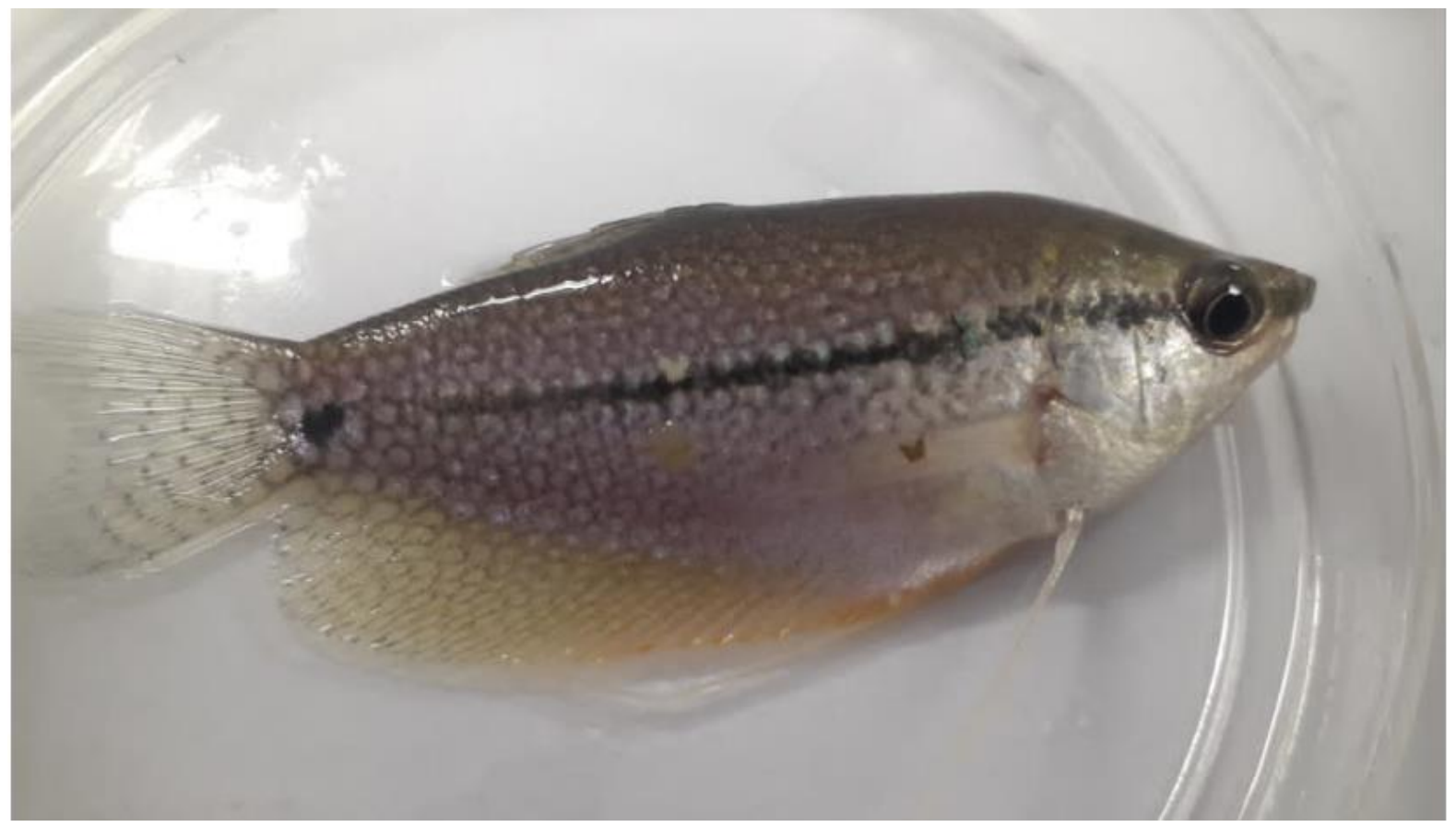

Figure 3. Trichopodus leeri.

\subsection{Fish Handling}

Prior to the arrival of the fishes, tanks were prepared and the water was let to stand to let chlorine evaporate, and all the tanks were set to a temperature of 24 degree Celsius. Upon their arrival, the fishes were acclimatised to the water in the glass tanks, following the protocol provided by the importing company. A pH and a temperature reading were taken for each of the water bags as well as for each tank. Then water was added to each bag with water from the glass tank that had the closest $\mathrm{pH}$ and temperature readings. The bag was opened and about $30 \%$ of water was removed from the bag and replaced with water from the selected glass tank. The bags were re-oxygenated using air pumps, resealed, and then allowed to float in its chosen glass tanks for $20 \mathrm{~min}$. This procedure was repeated twice. After floating of the bags, the fishes were gently released into the glass tanks. Fish were kept in the tank for less than $24 \mathrm{~h}$ before dissections commenced. Examination of fishes was performed at the University of Limpopo, Parasitology Laboratory. 


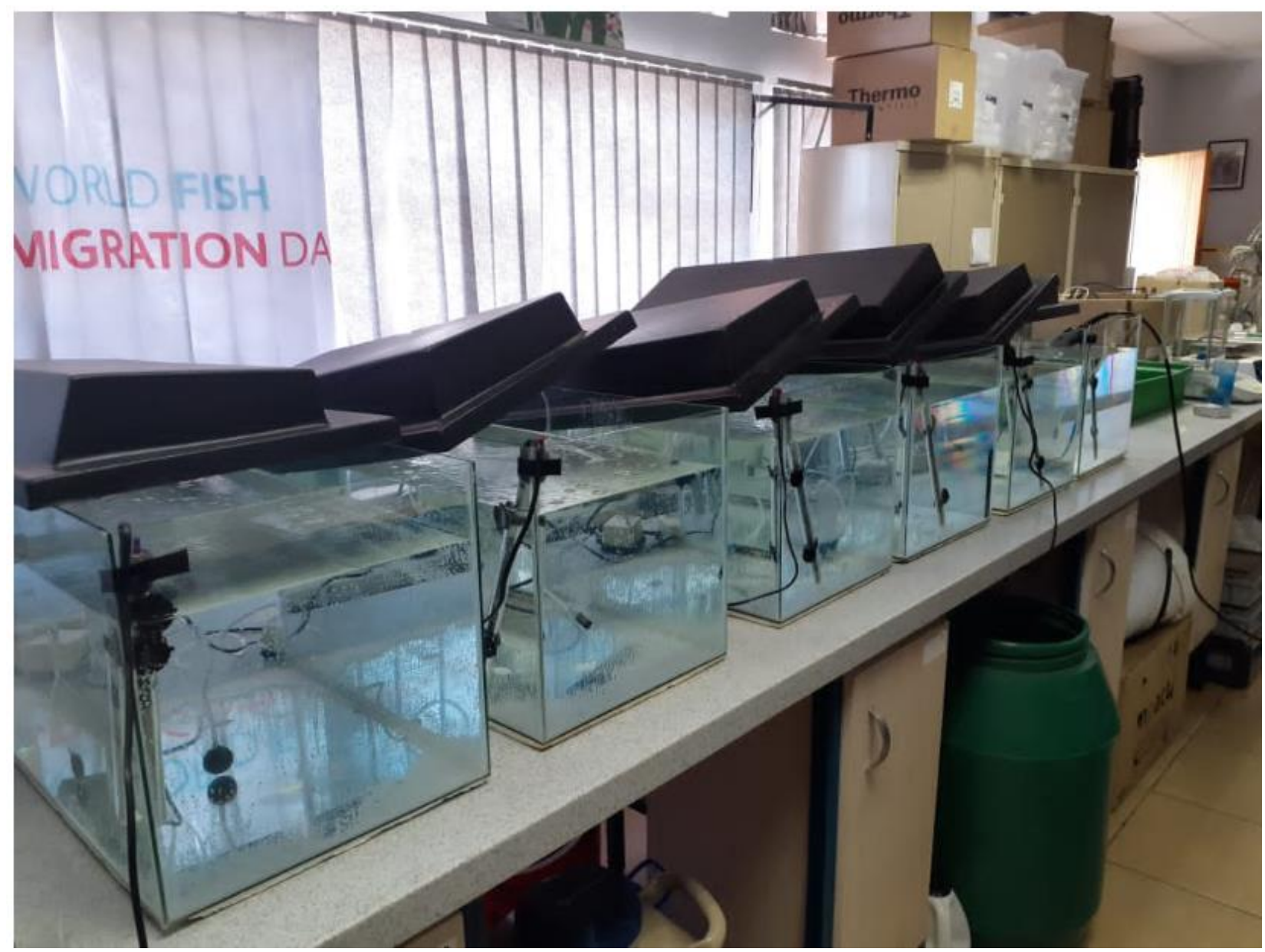

Figure 4. Set up for fish prior their arrival, Parasitology lab, University of Limpopo.

\subsection{Host Examination for Parasites}

Firstly, all of the fish species were examined for ectoparasites making use of a stereomicroscope (Leica EZ4) and viewing mucous smear slides made from the surface of the bodies and fins. Before a fish was dissected, it was euthanised by severing its spinal cord (Animal Ethics approval number AREC/01/2020: IR). Fish measurements including total length, standard length and fork length were taken. The mass of each fish was taken and recorded on a data sheet. The fish was dissected and internal organs and the gills were put in the separate petridishes. The presence of endoparasites of internal organs and monogeneans of the gills were examined using a compound microscope (Leica DM500).

\subsection{Fixation and Preservation of Parasites}

\section{Monogeneans}

Monogeneans were detached from gill filaments and placed on a microscope slide with a drop of water. They were covered with a cover slip, corners were sealed and a drop of Glycerine Ammonium Picrate (GAP) (Malmberg 1957) was added to the edges of the cover slip for fixation.

\section{Nematodes}

Parasites were removed from the fish, placed in a small amount of a saline solution. Hot water was poured on the parasites to ensure they are stretched. Nematodes that were used for identification were preserved in 70\% ethanol, and the rest in $96 \%$ ethanol for 
future molecular work. For the purpose of parasite identification, parasites were temporary placed under a cover slip in a drop of lactophenol to clear the nematode and ease observation of internal organs.

\section{Cestodes}

Cestode larvae found in the body cavity and intestine of fish were preserved in $70 \%$ ethanol or mounted on microscope slides using GAP.

\subsection{Identification of Collected Parasites}

A compound microscope (Olympus BX50) was used to identify parasites using the Stream Essentials program. Appropriate literature was used to identify each studied parasite species to the most possible classification level (Menezes et al. 2006; Scholz et al. 2018; Smit et al. 2018; Musilova et al. 2009). Morphological examinations were conducted to identify nematodes and cestodes. The shape and size of hooks were mainly used to identify mongeneans and cestodes.

\subsection{Infestation Indices}

Epidemiological indices were calculated as per methodology proposed by Bush et al. (1997). Prevalence and mean intensity of infections were calculated.

\section{Results}

The taken ranges of total length and weight for each species (Table 1) revealed that Trichopodus leeri can grow to the highest total length and weight, followed by Chromobotia macracanthus, then Glossolepsis incisus.

Table 1. Fish species and their numbers which were examined in the study.

\begin{tabular}{cccc}
\hline Fish Species & Number Collected & Total Length mm (Range) & Weight g (Range) \\
\hline Glossolepsis incisus & 21 & $48-69$ & $0.78-1.55$ \\
\hline Trichopodus leeri & 15 & $62-76$ & $3.13-5.25$ \\
\hline Chromobotia macracanthus & 15 & $65-81$ & $2.82-5.6$ \\
\hline
\end{tabular}

No parasites were found from Chromobotia macracanthus during this survey. The only abornamilty founds was small cysts in the gall bladder. Nematodes were recorded from T. leeri from the mid-length of the intestine, cestode larvae in the mid-length of intestine, in the body cavity and in the hind gut. Glossolepsis incius had monogeneans on their gill filaments, nematodes found mostly in the rectum and with some found in the mid-length of the intestine, and one single copepod on the dorsal fin.

\section{Infestation Indices}

Using information from Tables 1 and 2, the prevalence and mean intensity were calculated and the results are as follows. Glossolepsis incisus had 100\% prevalence for monogeneans and nematodes. The prevalence for copepods was $4.8 \%$, since only 1 fish had a copepod amongst the 21 examined. No cestode was found from this host. Intensity for monogenean infection was 12.81, 3.10 for nematodes and 0.05 for copepods. No monogeneans and copepods were recorded from T. leeri, the prevalence for nematodes was $26.67 \%$ and $46.67 \%$ for cestodes. Intensity for nematodes was 0.47 and 0.80 for cestodes.

Table 2. Type and number of parasites found from each fish.

\begin{tabular}{ccc}
\hline Parasite Host & Number of Parasites & Site \\
\hline Glossolepsis incisus & & \\
\hline Monogeneans & 269 & Gill filaments \\
\hline
\end{tabular}




\begin{tabular}{ccc}
\hline Nematodes & 65 & Rectum, intestine \\
\hline Cestodes & 0 & Dorsal fin \\
\hline Copepods & 1 & \\
\hline Trichopodus leeri & & Intestine \\
\hline Monogeneans & 0 & Intestine, body cavity \\
\hline Nematodes & 7 & \\
\hline Cestodes & 12 & \\
\hline Copepods & 0 &
\end{tabular}

\section{Cysts found in clown loach}

No parasites were recorded from the clown loach fish. However, some cysts (Figure $5 \mathrm{~A})$ were found in the gall bladder of some fish. After opening of the cysts, no definte parasite could be seen (Figure 5B). It is assumed maybe they were very early stage of a parasite but because of being fragile, they burst when opened and identification was not possible.

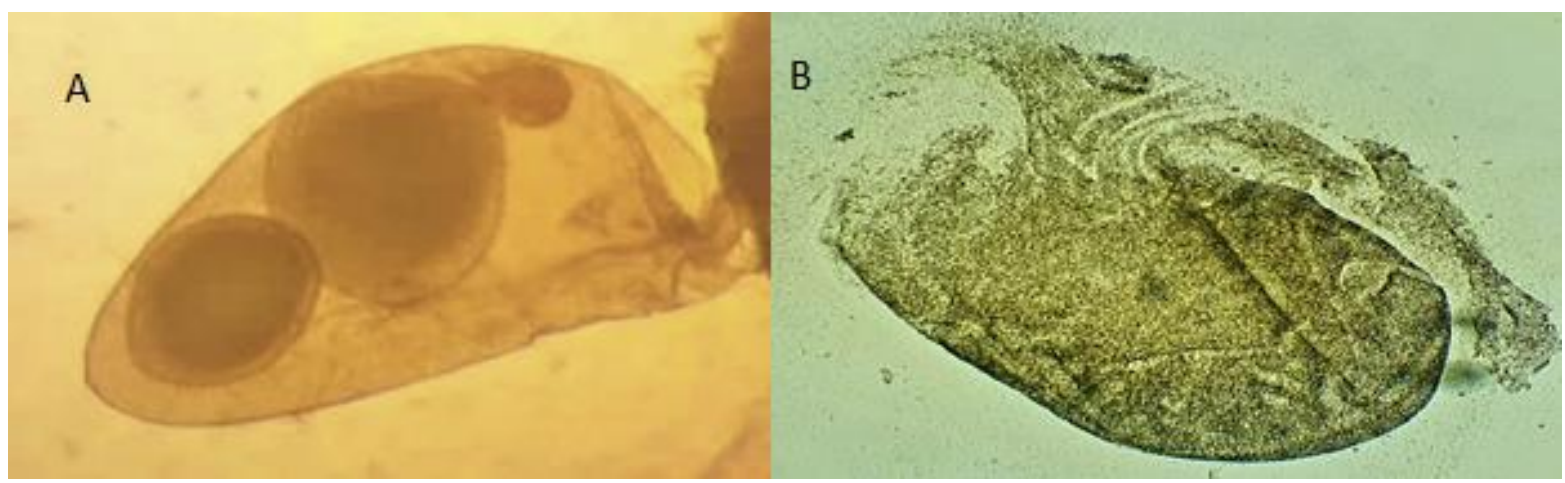

Figure 5. (A). Cysts within clown loach's gall bladder; (B). an opened cyst.

\section{Parasites from red rainbowfish}

Based on the unique combination of the haptoral hard parts (bars, anchors and hooks) seen in Figures 6 and 7, as well as measurement of the latter (Table 2), monogeneans found on the gills of red rainbow fish highly represent specimens of a new genus. The male copulatory organs (Figure 8) provided extra information for identification. Within the material collected, two species belonging to the family Ancyrocephalidae could be differentiated and here named as Ancyrocephalidae sp. 1 and Ancyrocephalidae sp. 2. Ancyrocephalidae sp. 1 infected $57.65 \%$ of the red rainbowfish, whilst Ancyrocephalidae sp. 2 infected $42.35 \%$ of them. 


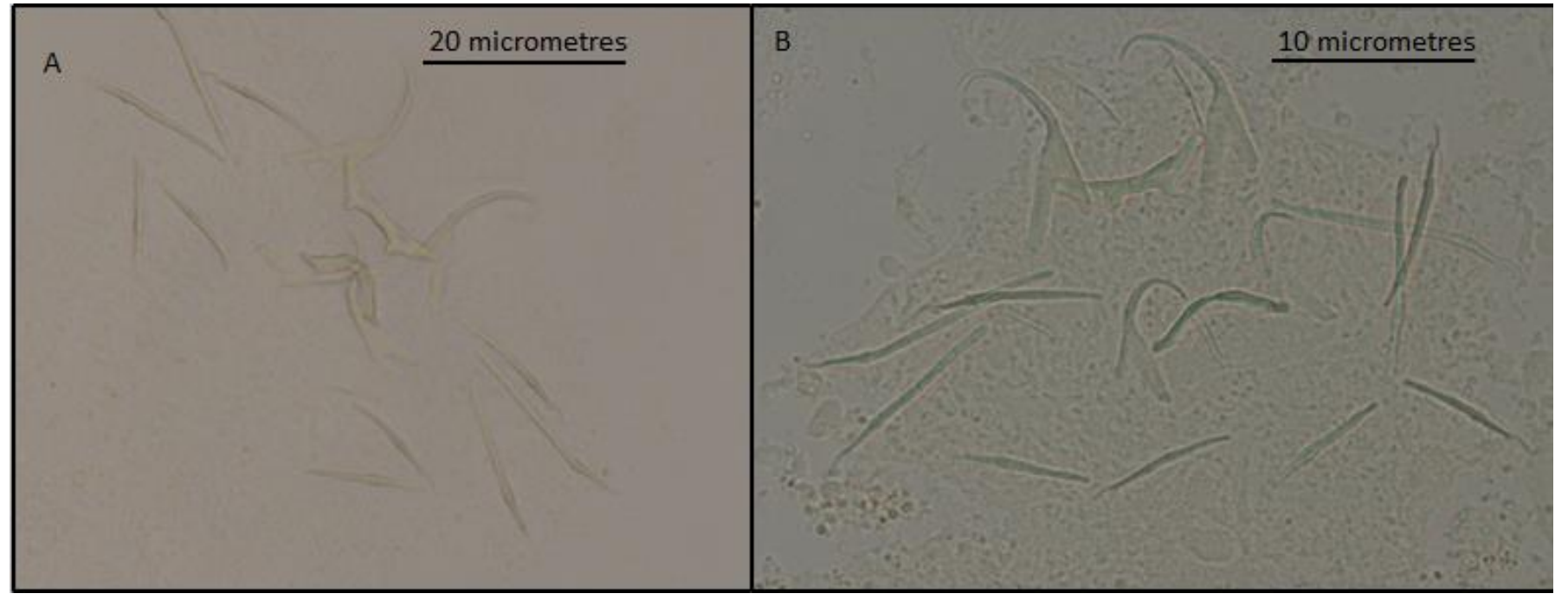

Figure 6. (A). Ancyrocephalidae sp.1; (B). Ancyrocephalidaesp.2; haptors overview.

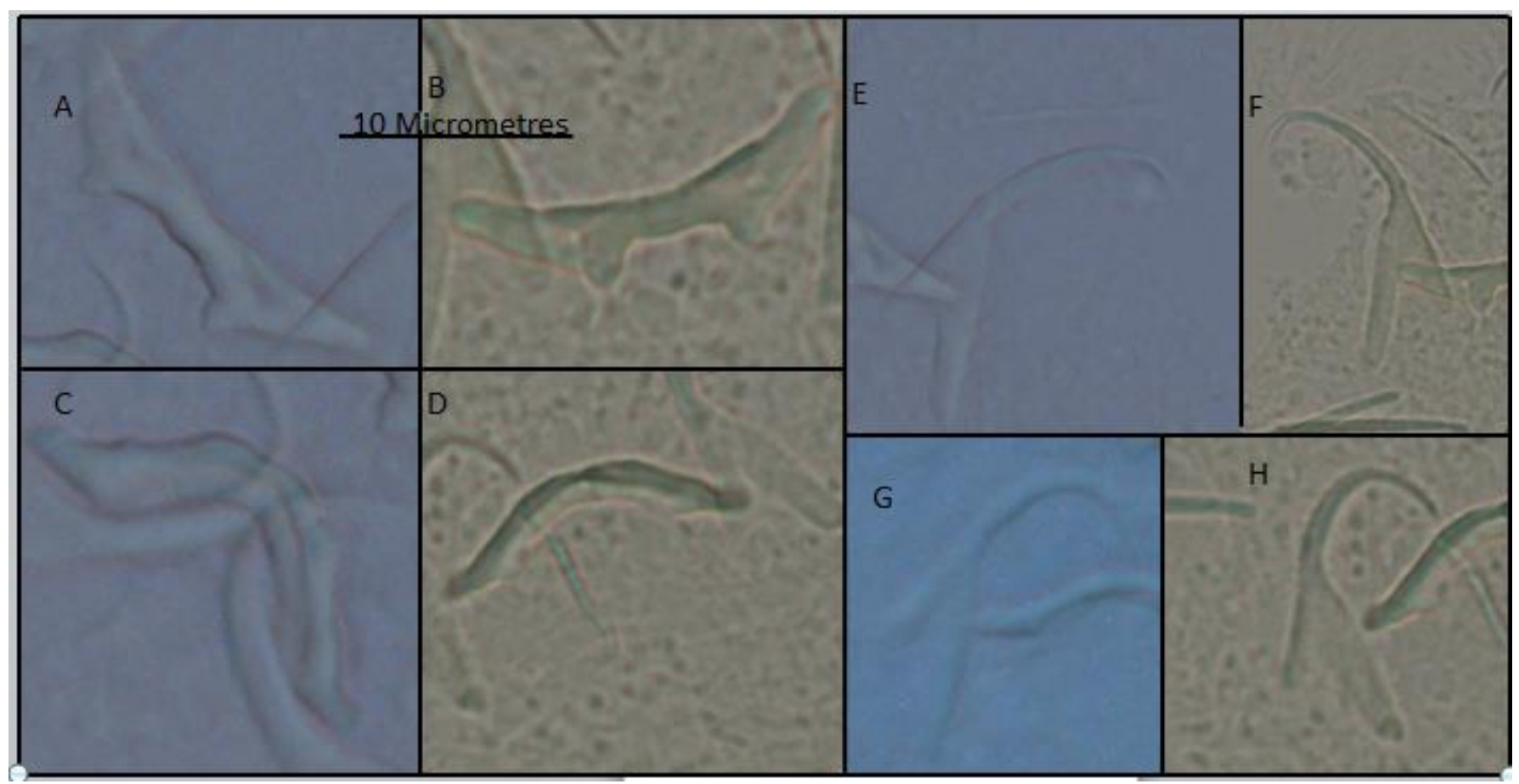

Figure 7. (A). Ancyrocephalidae sp.1, dorsal bar; (B). Ancyrocephalidae sp.2, dorsal bar; (C). Ancyrocephalidae sp.1, ventral bar; (D). Ancyrocephalidae sp.2, ventral bar; €. sp.1, dorsal anchor; (F). Ancyrocephalidae sp.2, dorsal anchor; (G). Ancyrocephalidae sp.1, ventral anchor; (H). Ancyrocephalidae sp.2, ventral anchor. 


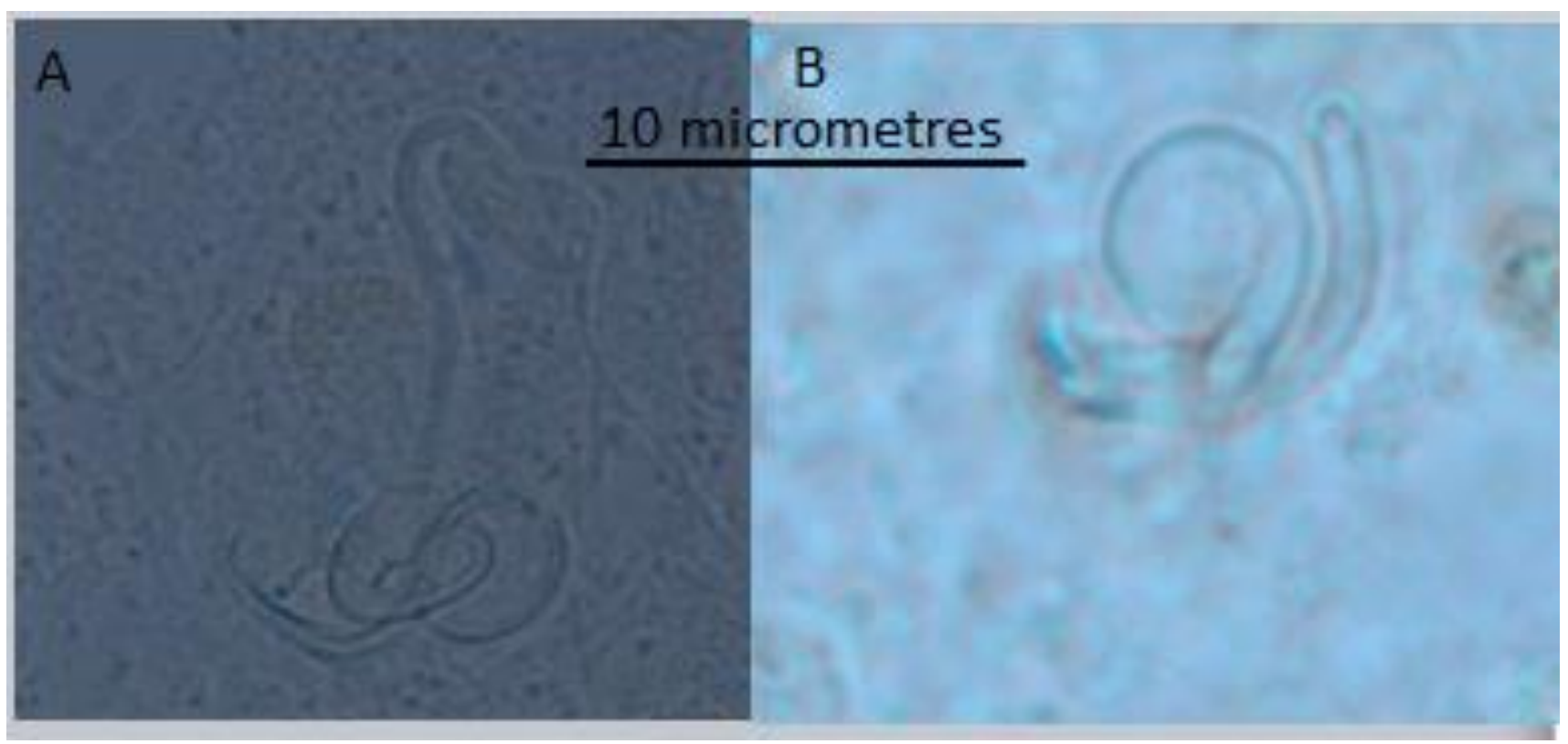

Figure 8. (A). Ancyrocephalidae sp. 1 and (B). Ancyrocephalidae sp. 2 male copulatory organs.

Table 3. Measurements (in micrometres) of haptoral hard parts of the monogenean parasites from the gills of Red rainbowfish.

Ancyrocephalidae sp. 1

$\mathrm{n}=4$

\section{Dorsal Anchor}

Inner Length

Outer Length

Inner Root

Outer Root

Point Length

Ventral Anchor

Inner Length

Outer Length

Inner Root

Outer Root

Point Length

Dorsal Bar

Total Length

Arm Length

Maximum Width

Ventral Bar

Total Length

Medium Width

Trace Length

\section{Hook}

$$
\text { I }
$$

II

III

IV

V

VI
29.72-33.56

27.71-30.77

10.21-13.07

3.76-6.39

4.31-5.91

19.91-23.21

17.51-19.7

6.93-8.51

2.52-3.54

4.9-6.52

26.89-29.88

8.35-9.69

10.26-12.46

21.26-24.58

3.85-5.64

24-26.27

13.48-15.07

23.7-25.39

31.26-35.22

39.63-44.71

16-17.48

23.34-25.25
Ancyrocephalidae sp. 2

$$
n=5
$$

\subsection{8-30.45 \\ 22.21-23.94 \\ 9.13-10.82 \\ 4.4-5.98 \\ 4.7-5.9}

18.86-20.42

14.16-15.85

5.78-7.57

1.7-3.8

4.79-6.13

22.71-25

5.74-8.07

10.06-11.79

19.56-21.33

3.81-4.6

22.26-24.42

10.63-13.49

20.95-23.65

29.01-31.21

38.13-41.51

15.8-16.8

20.29-21.63 
After morphological examination of nematodes (Figure 9), all the nematodes in the red rainbowfish were found to be Camallanus cotti Fujita, 1927. Before dissections, some of these nematodes were seen protruding through the anus of some red rainbow fish (Figure 10). These nematodes are viviparous and larvae could be seen in the body of one of the female worms (Figure 11).

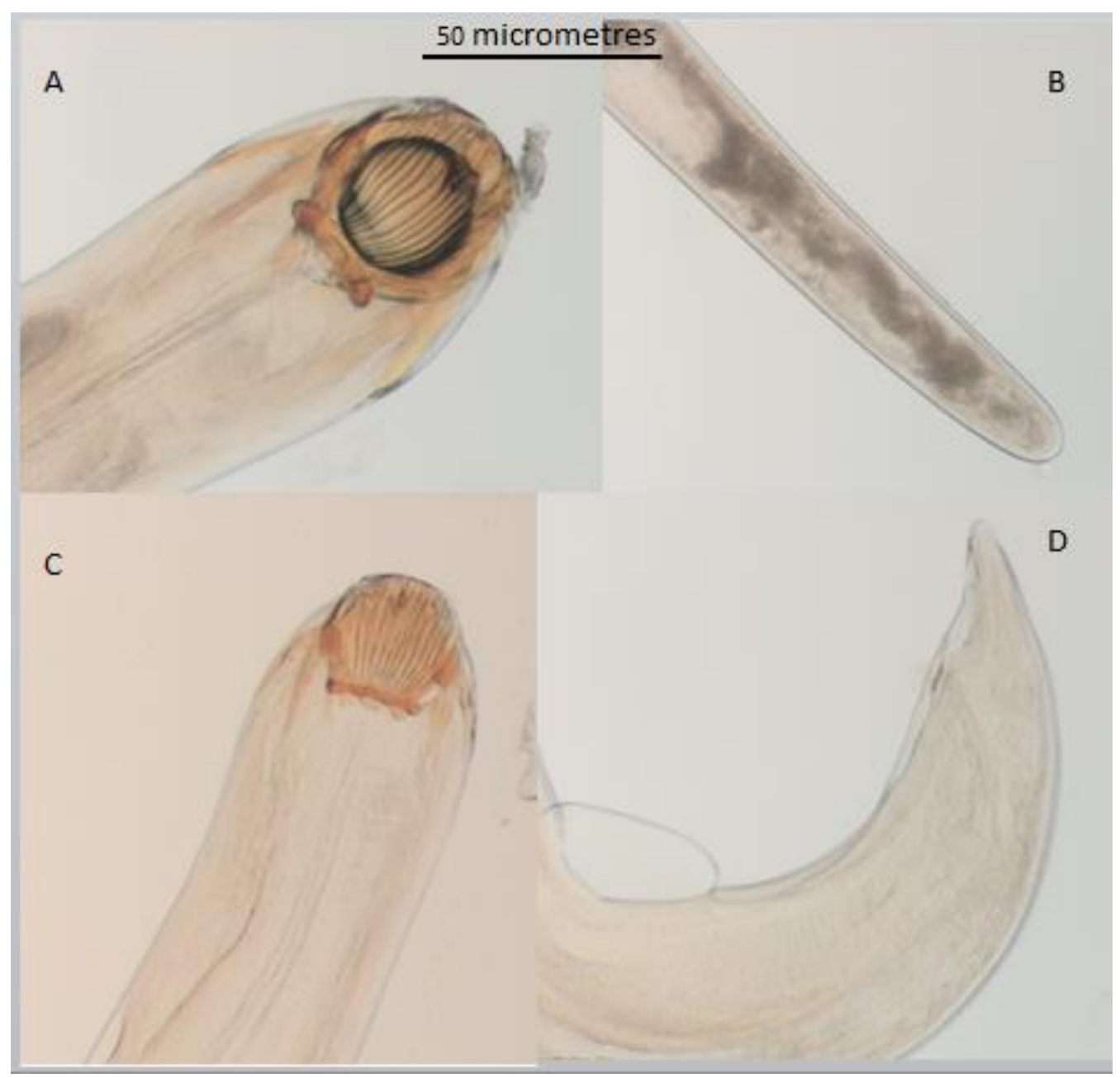

Figure 9. Camallanus cotti female, anterior end (A) and posterior end (B). Camallanus cotti male, anterior end $(\mathbf{C})$ and posterior end (D). 


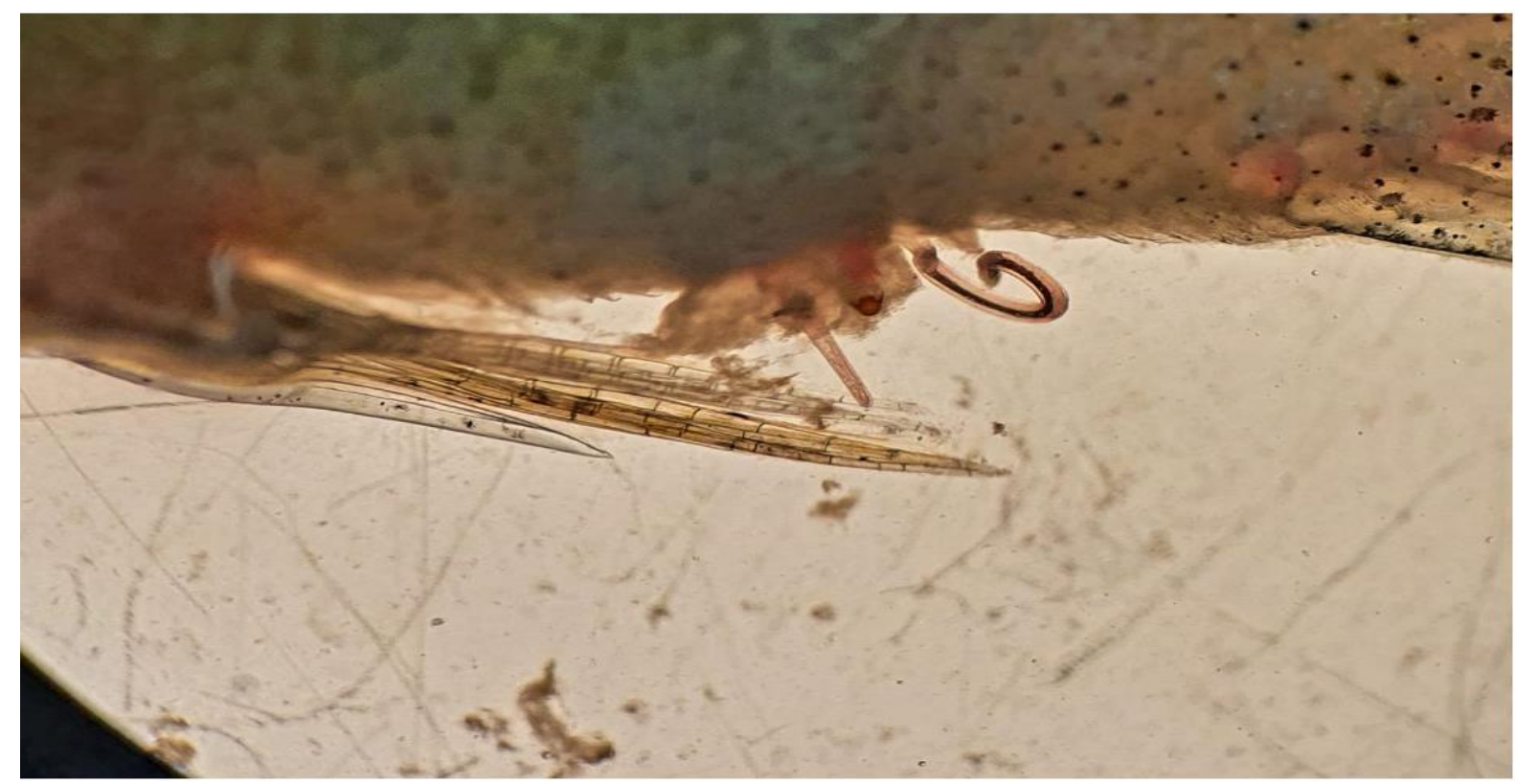

Figure 10. Nematode protruding through the anus of a red rainbow fish.

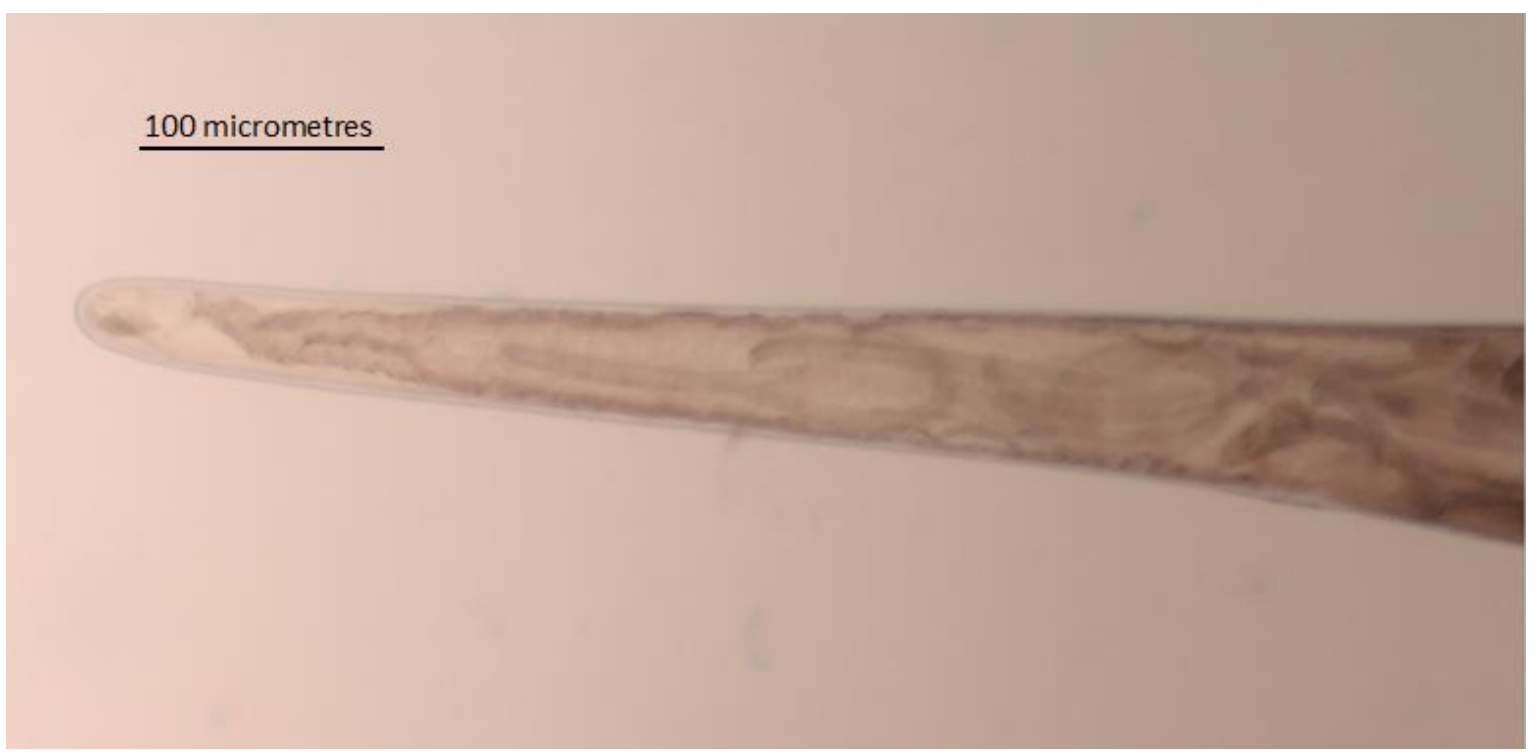

Figure 11. Camallanus cotti female with larvae.

By comparing the morphology of the copepod found on the dorsal fin of one red rainbowfish with the given literature, it was found to be Lernaea cyprinacea Linnaeus, 1758 (Figure 12). 


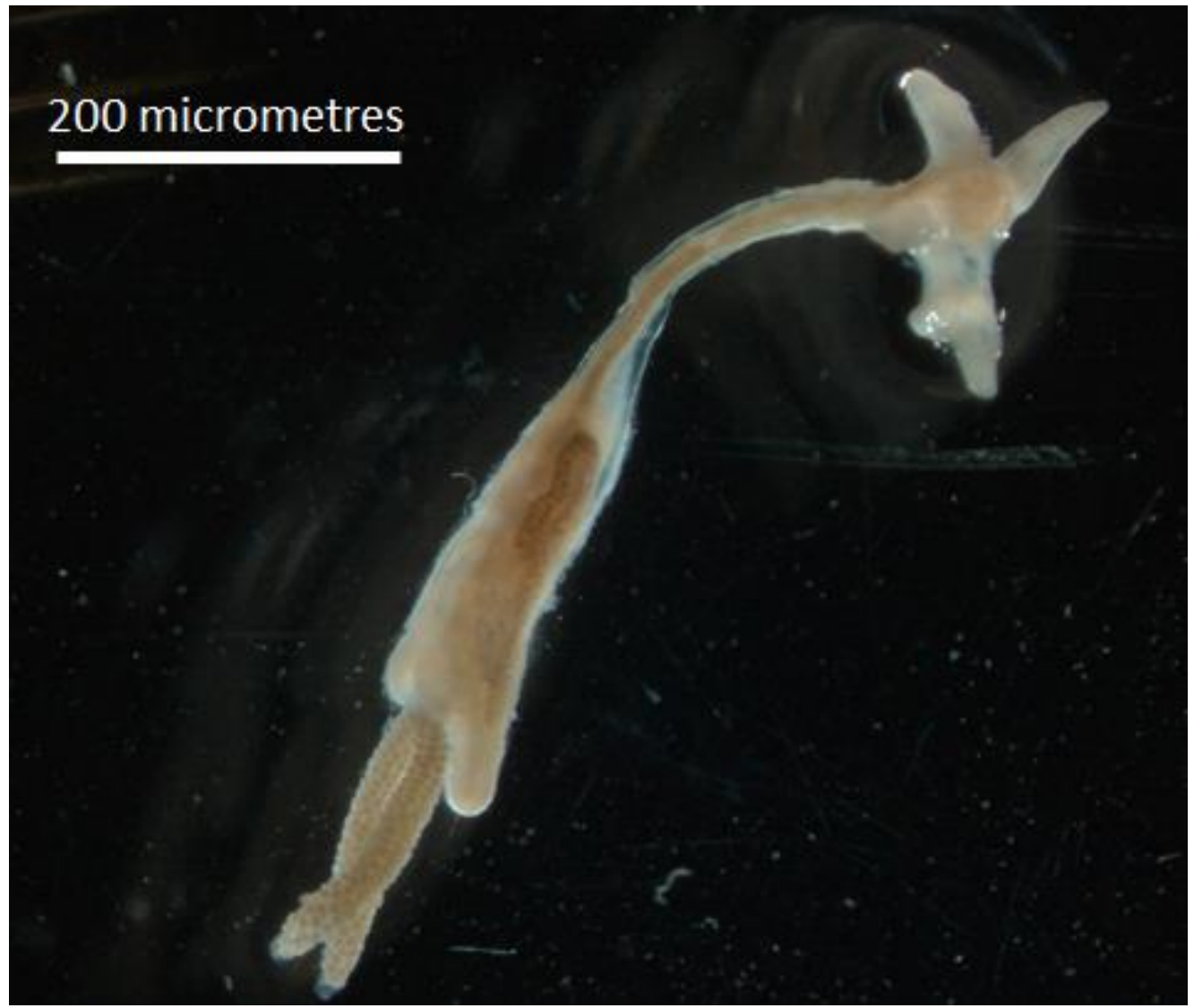

Figure 12. Lernaea cyprinacea.

\section{Identification of parasites of pearl gourami}

All the nematodes from pearl gourami were found to belong to the genus Procamallanus Baylis, 1923. The anterior (buccal capsule) and posterior ends (tail) are shown in Figure 13.

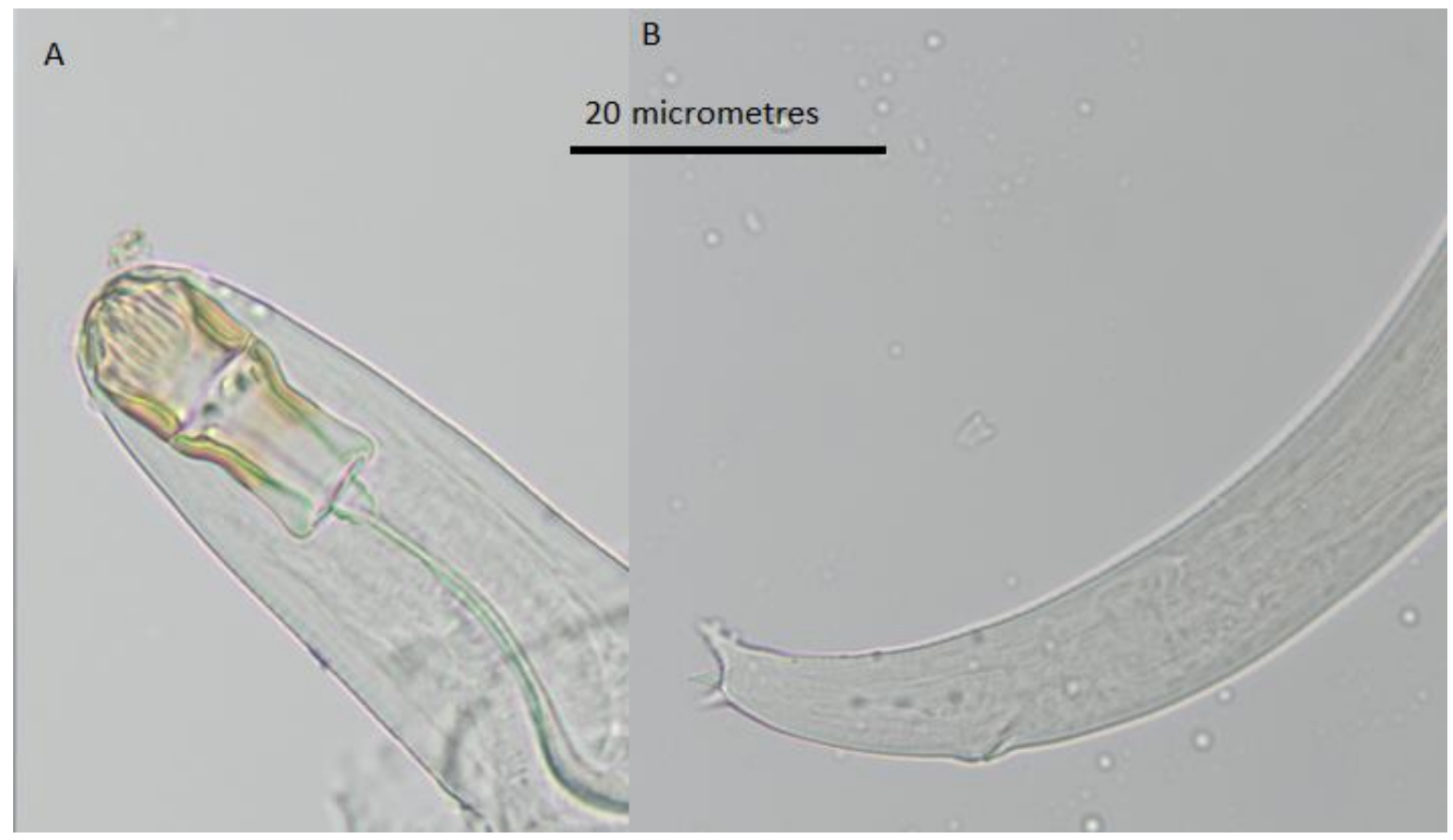

Figure 13. Procamallanus sp. anterior end (A) and posterior end (B). 
Two species from the family Gryporhynchidae were found, Neogryporhynchus cheilancristrotus and Dendrouterina herodiae. The calculations and shape of the hooks used to identify them are shown in Table 4 and Figure 14, respectively. Larval stage of one species was found to belong to the family Bothriocephalidae (Figure 15); the precise genus and species identification can't be performed without genetic data, as they were in larval stage.

Table 4. Hook lengths and ratio used to identify cestodes.

\begin{tabular}{|c|c|c|c|c|c|c|c|c|}
\hline \multirow{2}{*}{$\begin{array}{c}\begin{array}{c}\text { Neogryporhynchus } \\
\text { cheilancristrotus }\end{array} \\
\text { No. of the hooks 10:10 }\end{array}$} & \multicolumn{4}{|c|}{ Small hook } & \multicolumn{4}{|c|}{ Large hook } \\
\hline & $\begin{array}{r}\text { Total } \\
\text { length }\end{array}$ & $\begin{array}{c}\text { Blade } \\
\text { length (B) }\end{array}$ & $\begin{array}{c}\text { Handle } \\
\text { length }(\mathrm{H})\end{array}$ & $\mathrm{B} / \mathrm{H}$ ratio & $\begin{array}{r}\text { Total } \\
\text { length }\end{array}$ & $\begin{array}{c}\text { Blade } \\
\text { length (B) }\end{array}$ & $\begin{array}{c}\text { Handle } \\
\text { length }(\mathrm{H})\end{array}$ & $\mathrm{B} / \mathrm{H}$ ratio \\
\hline & 31.03 & 15.7 & 17.03 & 0.92 & 51.40 & 26.87 & 26.63 & 1.009 \\
\hline & 30.77 & 15.64 & 16.09 & 0.97 & 51.13 & 26.58 & 26.45 & 1.004 \\
\hline & 29.85 & 15.13 & 16.77 & 0.90 & 52.52 & 28.10 & 26.09 & 1.077 \\
\hline & & & & & 49.28 & 26.30 & 25.99 & 1.011 \\
\hline & & & & & 49.95 & 26.32 & 26.38 & 0.997 \\
\hline \multirow{6}{*}{$\begin{array}{l}\text { Dendrouterina herodiae } \\
\text { No. of the hooks 10:10 }\end{array}$} & \multicolumn{4}{|c|}{ Small hook } & \multicolumn{4}{|c|}{ Large hook } \\
\hline & $\begin{array}{r}\text { Total } \\
\text { length }\end{array}$ & $\begin{array}{c}\text { Blade } \\
\text { length (B) }\end{array}$ & $\begin{array}{c}\text { Handle } \\
\text { length }(\mathrm{H})\end{array}$ & $\mathrm{B} / \mathrm{H}$ ratio & $\begin{array}{l}\text { Total } \\
\text { length }\end{array}$ & $\begin{array}{c}\text { Blade } \\
\text { length (B) }\end{array}$ & $\begin{array}{c}\text { Handle } \\
\text { length }(\mathrm{H})\end{array}$ & $\mathrm{B} / \mathrm{H}$ ratio \\
\hline & 24.7 & 8.5 & 16.6 & 0.51 & 42 & 19.6 & 25.9 & 0.85 \\
\hline & 25.9 & 10.12 & 15.51 & 0.65 & 43.5 & 18.7 & 26.6 & 0.70 \\
\hline & 24.14 & 9.67 & 17.06 & 0.56 & 43.97 & 19.14 & 26.27 & 0.72 \\
\hline & & & & & & 19.02 & & \\
\hline
\end{tabular}

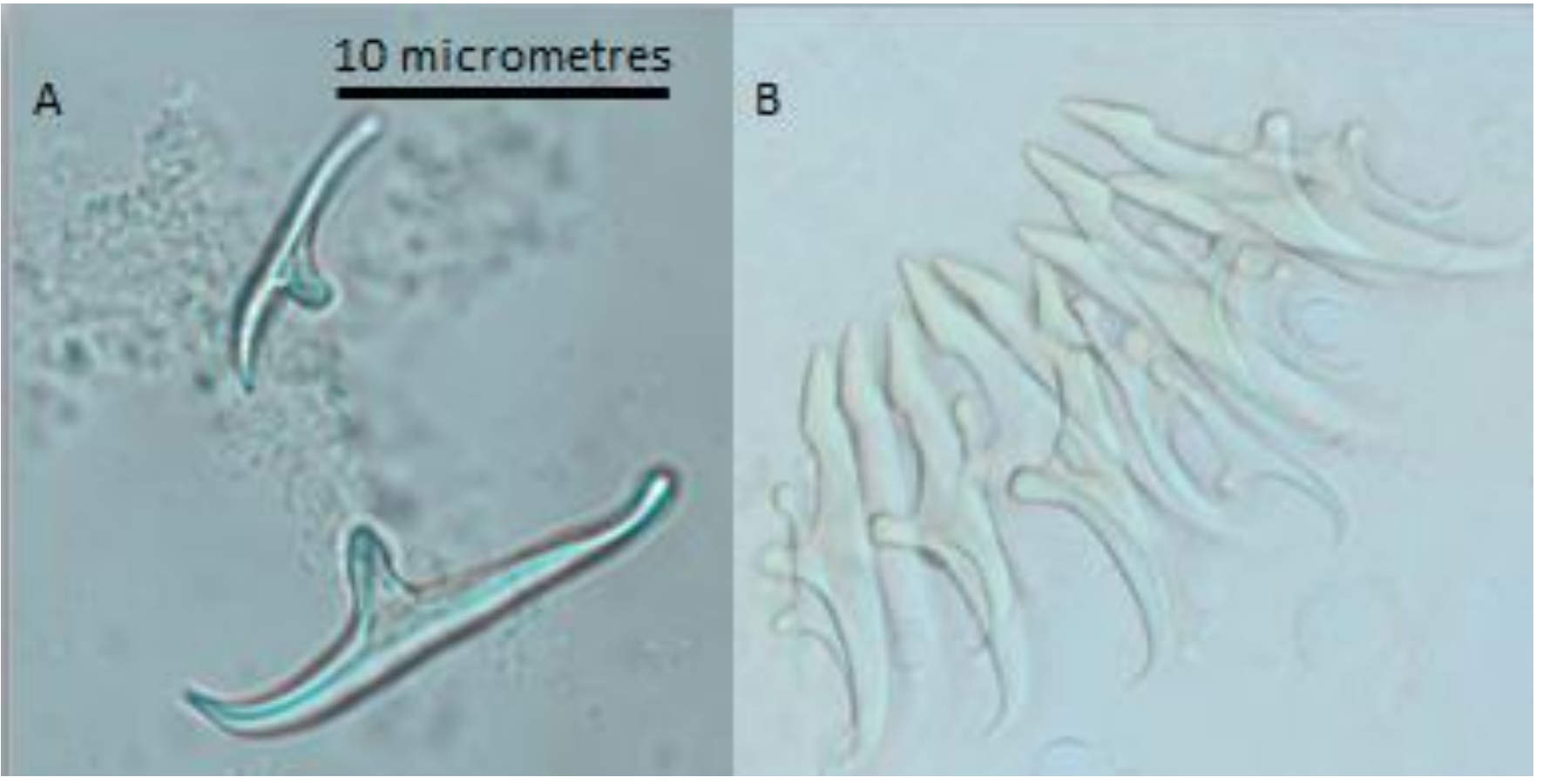

Figure 14. Neogryporhynchus cheilancristrotus, small and large hooks (A) and Dendrouterina herodiae, small and large hooks (B). 


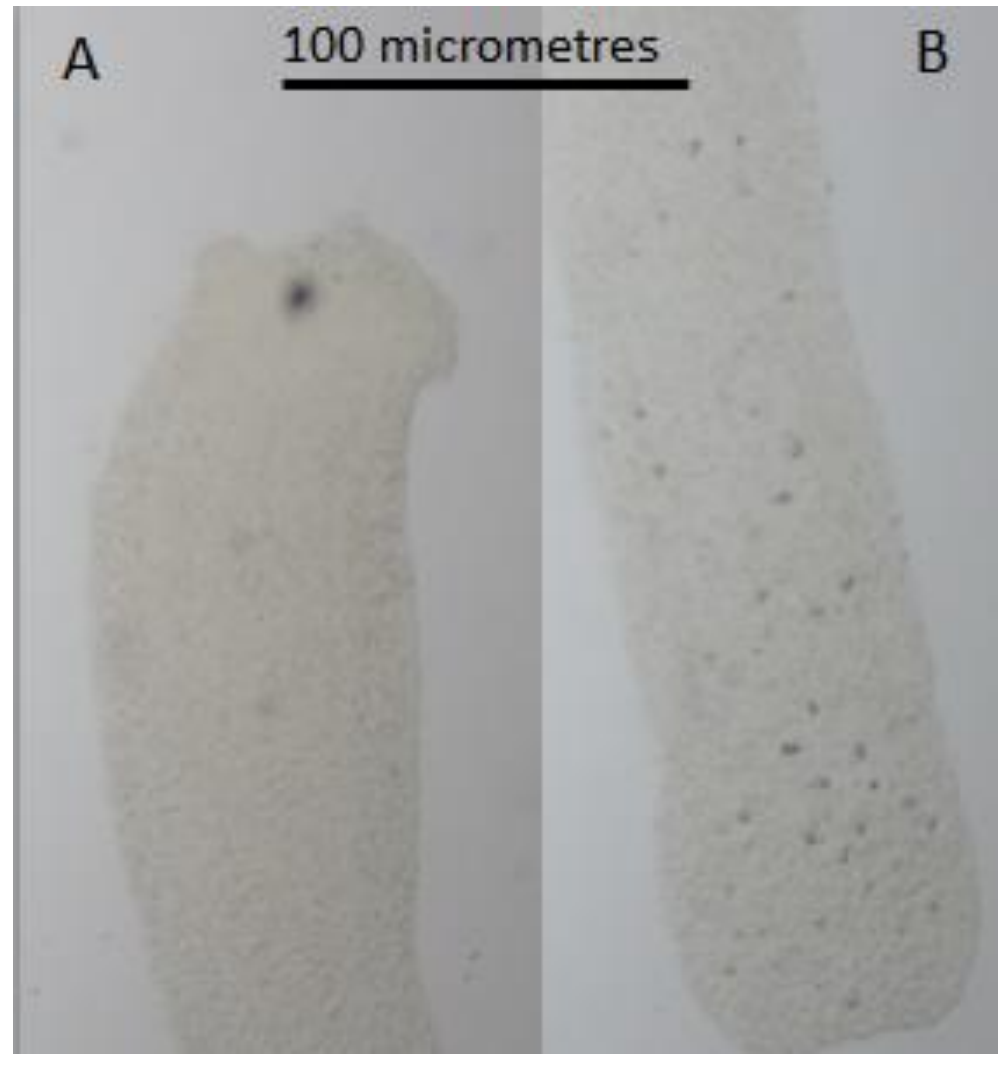

Figure 15. Anterior end (A) and posterior end (B) Bothriocephalidae sp.

\section{Discussion and Conclusions}

A high number of alien fish species have been introduced into Southern Africa for the purposes of using them as biological control agents, ornamental trade and for recreational angling (Macdonald et al. 2003). There's a long history of introduction of alien fish into South Africa making it globally one of the six hotspot countries for fish invasion (Leprieure et al. 2008), with 55 fish species having being introduced into South African freshwater ecosystems (Richardson et al. 2010). With global distribution of ornamental fish, the ornamental fish industry also distributes parasites to different countries (Adel et al. 2015), South Africa included (Tavakol et al. 2017). This might adversely affect the fish populations native to the area of introduction (Tavares-Dias et al. 2010).

To refresh the blood line, more fish are caught from the wild and introduced to aquaculture and in countries like Indonesia or Sri Lanka, they breed fish in outside ponds, thus the circulation of parasites is not eradicated. As much as this increases genetic diversity, it can also increase parasitic diversity. Parasites that co-evolved with their host are less or not harmful to the host they co-evolved with, but might cause great harm to those they did not co-evolved with (Hamilton and Zuk 1982). The examined specimens of red rainbowfish and pearl gourami revealed presence of parasites belonging to three phyla Nematoda, Platyhelminthes (class Cestoda and Monogenea) and Arthropoda (class Maxillopoda). Glossolepsis incisus was parasitised by the highest number of parasites with 269 monogeneans, 65 nematodes and 1 crustacean followed by $T$. leeri with seven nematodes and 12 cestodes. These results show that G. incisus might be potentially responsible for the translocation of monogenean species, and T. leeri mainly responsible for the translocation of cestodes species. This might mean that other fish species might have their own parasite group that they're mainly responsible for its distribution to different countries. Monogeneans are in the majority highly specific to their hosts, thus a spill over is not likely. In the case of cestodes and their hosts being eaten by birds, they can get transferred into the ecosystem. Similarly, with nematodes, if they would find intermediate hosts to complete their life cycle, then it will be possible for themto spread. Therefore, this might mean, each 
alien species introduced to South Africa (or any other country) might have its own unique negative effect on the native fish population. In simpler terms, the more different alien species are introduced in South Africa, the more different problems the native fish populations might have. Not a single parasite was found from C. macracanthus, but cysts that were later found to be containing no definite parasite were found in their gall bladders.

The only ectoparasites that were found on the examined fish were monogeneans and one copepod. The class Monogenea consists of a variety of species with most found on gills, but also can be on the body surface, fins, and limited number of species in the internal organs (Luus-Powell et al. 2020). Monogenean species are being continually discovered to be infecting more species, with numerous monogeneans being found to have infected cichlids in Africa (Prikrylova et al. 2009). In this study the collected and identified monogeneans were found to belong to the family Ancyrocephalidae. The collected monogeneans were identified to family level only, with them having enough differences within them in such a way that it was not possible to allocate them into any currently known genus. Monogeneans collected might represent new species of a new genus, and this is highly probable since the parasites' host is endemic to Indonesia (with a very small area of distribution) and not much study on monogeneans is done there. The host is an endemic fish and has not been previously studied for parasites. As shown in studies of Benovics et al. (2017), Benovics et al. (2018) and Benovics et al. (2020), endemic hosts might hide many undescribed species as has been shown recently on European cyprinoids. This discovery of new species contributes knowledge to parasite species diversity. Ancyrocephalidae sp. 1 infected more red rainbowfish (Infecting 57.65\% of them) than Ancyrocephalidae sp. 2. There have been recorded cases whereby monogenean parasites greatly disrupted the fish population. Several decades ago, microcotylid and capsalid monogeans caused mortalities of several fish that were kept in public aquariums (Nigrelli 1943). The mortalities could have been due to severe anemia brought about the monogeneans overwhelming the fish (Paperna et al. 1984). In Japan the same monogeneans led to the mass mortalities of cultured Yellowtail fish (Hoshina 1968). In an experiment by Paperna et al. (1984) to see the effect of monogenean infestation, a group of monogenean free fish were mixed with infested fish in a cage. The newly infested fish were observed and within three to four weeks they either died or were morbid. The results also showed that those with a relatively low infestation were able to recover, whilst those with a high infestation eventually died.

Camallanus cotti and Procamallanus sp. were the nematodes identified from the studied fishes. The genus Camallanus is often recognised by the worms having a shade of a red colour and they can be seen protruding through the anus of their hosts. The genus Camallanus is species rich, consisting of over 120 species (Moravec et al. 2003). Species within the Camallanus genus often affect their hosts in similar ways. They are known to cause severe intestinal lesions, leading to the eventual deaths of their hosts. Camallanus cotti, a common parasite of ornamental fishes, causes these lesions when it's feeding in the intestine of its host. The damage occurs whereby as the worm feeds on the host's blood, it also partially eats off a part of its intestinal wall (McMinn 1990). The other nematode found in the present study was Procamallanus sp. Procamallanus consists mostly of parasitic species parasitising both freshwater and marine fish (Andrade-Salas et al. 1994). So far three nominal Procamallanus species have been described in Africa (Boomker 1994). Other endoparasites that were found were cestode larvae belonging to the families Gryporhynchidae and Bothriocephalidae. Gryporhynchidae larvae were first discovered in Camargue, France and up to now have been reported in various African countries such as Kenya, Mozambique and South Africa (Truter et al. 2016; Scholz et al. 2018). The Gryporhynchidae larvae identified in the present study are Neogrypothynchus cheilancristrotus and Dendrouterina herodiae. Larvae of Gryporhynchidae infect a variety of fish as intermediate hosts including Tilapia sparrmanii Smith, 1840 and Cyprinus carpio Linnaeus, 1758 (Scholz et al. 2018), and can occupy different internal organs of host fish (Scholz et al. 2013). Adult Gryporhynchidae species will then reach their final hosts, which are fish eating birds such 
as herons (Baer and Bona 1960). Even though, due to their species richness, the Gryporhynchidae can infect a high range of host species, there are few cases whereby larval infection was pathogenic to the host (Scholz and Salgado-Maldonando 2001). Unlike those from Gryporhynchidae, species from the family Bothriocephalidae are not only pathogenic but can cause high mortalities to their hosts (Yeh 1995). More invasion concerns should be directed at the Bothriocephalidae compared to the Gryporhynchidae. This is because Bothriocephalidae family species are not host specific, there's therefore a possibility that a single species of the family can infect and affect a variety of host species. Parasites of Bothriocephalidae have been recorded infecting above 200 cultured and wild fish species (Yera et al. 2013).

\section{Conclusion}

The aim of the study was to examine the parasite diversity of three ornamental fish species from fish importers. Four different groups of parasites were found, endoparasites consisting of cestodes and nematodes, and ectoparasites consisting of two unknown species of monogeneans and a crustacean. The present study shows that studies done on ornamental fish can be a source of finding new parasites and thus contributing to the knowledge of parasites diversity. Translocation of the fish hosts exposes parasites to hosts they did not co-evolve with, making them potentially pathogenic to their new hosts. It is therefore important to quarantine ornamental fish prior to their distribution to different countries as well as do a screening for parasites. It is important to maintain indigenous diversity not only for the reason of ensuring that future generations get to experience all the living species of the present generation, but also for the importance biodiversity plays in an ecosystem. Introduction of ornamental fish along with their parasites might not only affect fish diversity in South Africa, but might have an effect on other species such as birds who might feed on these alien fish and also other species to which the bird species are prey.

\section{Institutional Review Board Statement:}

\section{Informed Consent Statement:}

\section{Data Availability Statement:}

Acknowledgments: I Prikrylova for handling importation of fishes, and assisting with their acclimatisation, dissections, fixation, preservation and identification of their parasites and recommending literature to study. S Tavakol for assisting with dissections of fishes, fixation and preservation of parasites, identification of cestodes and recommending literature to study. WJ Luus-Powell for assisting with dissections of fishes, fixation and preservation of parasites, advices on how to format the mini-dissertation, and recommending literature to study. N Kmetova for assisting with identifications for monogeneans. WCB imports (Midrand) for providing the fishes (from Aquazone, Indonesia) and their acclimatisation procedure. CN Mashilwane, for assisting with fishes' acclimatisation and dissections, parasite fixing and preservation, and taking pictures of fishes for the study. My mother for persistent motivations and encouragements. This work is based on the research supported by the South African Research Chairs Initiative of the Department of Science and Innovation and National Research Foundation of South Africa (Grant No. 101054). Any opinion, finding and conclusion or recommendation expressed in this material is that of the author(s) and the NRF does not accept any liability in this regard.

\section{References}

1. Adel, M.; Ghasempour, F.; Azizi, H.R.; Shateri, M.H.; Safian, A.R. Survey of parasitic fauna of different ornamental freshwater fish species in Iran. Vet. Res. Forum Int. Q. J. 2015, 6, 75-78.

2. Adlard, R.D.; Miller, T.L.; Smit, N.J. The butterfly effect: Parasite diversity, environment, and emerging disease in aquatic wildlife. Trends Parasitol. 2015, 31, 160-166.

3. Alien, G.R. A generic classification of the rainbowfishes (family Melanotaeniidae). Rec. West. Aust. Mus. 1980, 8, 449-490.

4. Allen, G.R. Field Guide to the Freshwater Fishes of New Guinea; Christensen Research Institute: 1991; p. 268.

5. Andrade-Salas, O.; Pineda-lo' pez, R.; Garci A-Magan, L. Spirocamallanus rebecae sp. n. (Nematoda: Camallanidae) from freshwater fishes in south-eastern Mexico. Folia Parasitol. 1994, 41, 259-270. 
6. Baer, J.G.; Bona, F.V. Re'vision des Cestodes Dilepididae Fuhrm., 1907 des Arde'iformes. Note pre'limi-naire. Bolletino dell'Istituto e Museo di Zoologia della Universita` di Torino 1960, 6, 91-143.

7. Benovics, M.; Desdevises, Y.; Šanda, R.; Vukić, J.; Šimková, A. Cophylogenetic relationships between Dactylogyrus (Monogenea) ectoparasites and endemic cyprinoids of the north-eastern European peri-Mediterranean region. J. Zool. Syst. Evol. Res. 2020, 58, 1-21.

8. Benovics, M.; Desdevises, Y.; Vukić, J.; Šanda, R.; Šimková, A. The phylogenetic relationships and species richness of hostspecific Dactylogyrus parasites shaped by the biogeography of Balkan cyprinids. Sci. Rep. 2018, 8, 1-18.

9. Benovics, M.; Kičinjaová ML, Šimková, A. The phylogenetic position of the enigmatic Balkan Aulopyge huegelii (Teleostei: Cyprinidae) from the perspective of host-specific Dactylogyrus parasites (Monogenea), with a description of Dactylogyrus omenti n. sp. Parasites Vectors 2017, 10, 1-13.

10. Boomker, J. Parasites of South African freshwater fishes. VI. Nematode parasites of some fish species in the Kruger National Park. Onderstepoort J. Vet. Res. 1994, 61, 35-43.

11. Bush, A.O.; Laffert, K.D.; Lots, T.M.; Shostak, W. Parasitology meets ecology on its own terms: Margolis et al. revisited. J. Parasitol. 1997, 83, 575-583.

12. Bruton, M.N.; Van As, J. Faunal Invasions of Aquatic Ecosystems in Southern Africa, with Suggestions for Their Management; Oxford University Press: Oxford, UK, 1986; pp. 47-61.

13. Ellender, B.R.; Weyl, O.L. A review of current knowledge, risk and ecological impacts associated with non-native freshwater fish introductions in South Africa. Aquat. Invasions 2014, 9, 177-178.

14. Eschmeyer, W.N.; Fricke, R.; Van Der Laan, R. Catalog of Fishes Electronic Version. California Academy of Sciences. 2012. Available online: http://research.calacademy.org/research/ichthyology/catalog/fishcatmain.asp (accessed on).

15. Goyal, A.K. Invasive Alien Species threat to biodiversity and economy of the country. Indian For. 2005, 131, 1529-1536.

16. Gozlan, R.E.; Britton, J.R.; Cowx, I.; Copp, G.H. Current knowledge on non-native freshwater fish introductions. J. Fish Biol. 2010, 76, 751-786.

17. Graham, J.B.; Lee, H.J. Breathing air in air: In water ways might extant amphibious fish biology relate to prevailing concepts about early tetrapods, the evolution of vertebrate air breathing, and the vertebrate land transition. Physiol. Biochem. Zool. 2005, 77, 720-731.

18. Hamilton, W.D.; Zuk, M. Heritable true fitness and bright birds: A role for parasites. Science 1982, 218, $384-387$.

19. Hoshina, T. On the monogenetic trematode Benedenia seriolae, parasitic on yellowtail, Seriola quinqueradiata. Bull. L'office Int. Epizoot. 1968, 69, 1179-1191.

20. Huang, C.Y.; Lee, W.; Lin, H.C. Functional differentiation in the anterior gills of the aquatic air-breathing fish, Trichogaster leeri. J. Comp. Physiol. B 2008, 178, 111-121.

21. Kadarini, T.; Zamroni, M.; Pambayuningrum, E.K. Development of the kurumoi rainbowfish larvae (Melanotaenia parva). J. Ris. Akuakultur 2013, 8, 77-86.

22. Kathiresan, R.M.; Gnanavel, I.; Anbhazhagan, R.; Padmapriya, S.P.; Vijayalakshmi, N.K.; Arulchezhian, M.P. Ecology and control of Parthenium invasion in command area. In Proceedings of Second International Conference on Parthenium Management, 2005; pp. 5-7.

23. Kottelat, M. Botia kubotai, a new species of loach (Teleostei: Cobitidae) from the Ataran River basin (Myanmar), with comments on botiine nomenclature and diagnosis of a new genus. Zootaxa 2004, 401, 1-18.

24. Legendre, M.; Satyani, D.; Subandiyah, S.; Pouyaud, L.; Baras, E.; Slembrouck, J. Biology and culture of the clown loach Chromobotia macracanthus (Cypriniformes, Cobitidae): 1-Hormonal induced breeding, unusual latency response and egg production in two populations from Sumatra and Borneo Islands. Aquat. Living Resour. 2012, 25, 95-108.

25. Leprieure, F.; Beauchard, O.; Blanchet, S.; Oberdorff, T.; Brosse, S. Fish invasions in the world's river systems: When natural processes are blurred by human activities. Plos Biol. 2008, 6, 28-38.

26. Luus-Powell, W.J.; Madanire-Moyo, G.N.; Matla, M.M.; Přikrylová, I. Monogenean parasites from the stomach of Oreochromis mossambicus from South Africa: Two new species of Enterogyrus (Dactylogyridae: Ancyrocephalinae). Parasitol. Res. 2020, 1-10.

27. Lymbery, A.J.; Morine, M.; Kanani, H.G.; Beatty, S.J.; Morgan, D.L. Co-invaders: The effects of alien parasites on native hosts. Int. J. Parasitol. Parasites Wildl. 2014, 3, 171-177.

28. Macdonald, I.A.W.; Reaser, J.K.; Bright, C.; Neville, L.E.; Howard, G.W.; Murphy, S.J.; Preston, G. Invasive Alien Species in Southern Africa: National Reports and Directory of Resources; Global Invasive Species Programme: 2003; pp. 9-40.

29. Malmberg, G. On a new genus of viviparous monogenetic trematode. Ark. Zool. 1957, 10, 317-329.

30. McMinn, H. Effects of the nematode parasite Camallanus cotti on sexual and non-sexual behaviors in the guppy (Poecilia reticulata). Am. Zool. 1990, 30, 245-249.

31. Menezes, R.C.; Tortelly, R.; Tortelly-Neto, R.; Noronha, D.; Pinto, R.M. Camallanus cotti Fujita, 1927 (Nematoda, Camallanoidea) in ornamental aquarium fishes: Pathology and morphology. Memórias Do Inst. Oswaldo Cruz 2006, 101, $683-687$.

32. Moravec, F.; Nie, P.; Wang, G.T. Some nematodes of fishes from central China, with redistribution of Procamallanus (Spirocamallanus) fulvidraconis (Camallanidae). Folia Parasitol. 2003, 50, 220-230.

33. Mouton, A.; Basson, L.; Impson, D. Health Status of Ornamental Freshwater Fishes Imported to South Africa: A Pilot Study. Aquar. Sci. Conserv. 2001, 3, 313-319.

34. Nigrelli, R.F. Causes of diseases and death of fishes in captivity. Zoologica 1943, 28, 203-216. 
35. Paperna, I.; Diamant, A.; Overstreet, R.M. Monogenean infestations and mortality in wild and cultured Red Sea fishes. Helgoländer Meeresunters. 1984, 37, 445-462.

36. Přikrylová I, Matějusová I, Musilová, N.; Gelnar, M. Gyrodactylus species (Monogenea: Gyrodactylidae) on the cichlid fishes of Senegal, with the description of Gyrodactylus ergensi n. sp. from Mango tilapia, Sarotherodon galilaeus L. (Teleostei: Cichlidae). Parasitol. Res. 2009, 106, 1-6.

37. Richardson, D.M.; Wilson, J.R.; Weyl, O.; Griffiths. South Africa: Invasions. In Encyclopedia of Biological Invasions (Encyclopedias of the Natural World); Simberloff, D., Rejmanek, M., Eds.; University of California Press: 2010; pp. 643-651.

38. Roberts, T.R. The freshwater fishes of Western Borneo (Kalimantan Barat, Indonesia). Calif. Acad. Sci. 1989, 14, 1-210.

39. Scholz, T.; Aguirre-Macedo, M.L.; Salgado-Maldonado, G. Trematodes of the family Heterophyidae (Digenea) in Mexico: A review of species and new host and geographical records. J. Nat. Hist. 2001, 35, 1733-1772.

40. Scholz, T.; Bray, R.A.; Kuchta, R.; Repová, R. Larvae of gryporhynchid cestodes (Cyclophyllidea) from fish: A review. Folia Parasitol. 2013, 51, 131-152.

41. Scholz, T.; Tavako, S.; Uhrová L, Brabec jan, Přikrylová I, Mašová S, Šimková A, Halajian, A.; Luus-Powell, W.J. An annotated list and molecular data on larvae of gryporhynchid tapeworms (Cestoda: Cyclophyllidea) from freshwater fishes in Africa. Syst. Parasitol. 2018, 95, 567-590.

42. Siby, L.S.; Rahardjo, M.F.; Sjafei, D.S. BIOLOGI REPRODUKSI IKAN PELANGI MERAH (Glossolepis Incisus, Weber 1907) DI DANAU SENTANI [Reproductive Biology of Red Rainbowfish (Glossolepis Incisus Weber 1907) in Sentani Lake]. J. Iktiologi Indones. 2017, 9, 49-61.

43. Smit, N.; Basson, L.; Vanhove, M.P.; Scholz, T. History of fish parasitology in Africa. In A Guide to the Parasites of African Freshwater Fishes; 2018; pp.15-30.

44. Smit, N.J.; Malherbe, W.; Hadfield, K.A. Alien freshwater fish parasites from South Africa: Diversity, distribution, status and the way forward. Int. J. Parasitol. Parasites Wildl. 2017, 6, 386-401.

45. Tavakol, S.; Halajian, A.; Smit, W.J.; Hoffman, A.; Luus-Powell, W.J. Guppies (Poecilia reticulata) introducing an alien parasite, Camallanus cotti (Nematoda: Camallanidae) to Africa, the first report. Parasitol. Res. 2017, 116, 3441-3445.

46. Musilova, N.; Rehulkova, E.; Gelnar, M. Dactylogyrids (Platyhelminthes: Monogenea) from the gills of the African carp, Labeo coubie Ruppell (Cyprinidae), from Senegal, with descriptions of three new species of dactylogyrus and the redescription of Dactylogyrus cyclocirrus Paperna, 1973. Zootaxa 2009, 2241, 47-68.

47. Tavares-Dias, M.; Lemos, J.R.G.; Martins, M.L. Parasitic fauna of eight species of ornamental freshwater fish species from the middle Negro River in the Brazilian Amazon Region. Rev. Bras. Parasitol. Veterinária 2010, 19, $103-107$.

48. Truter, M.; Pr`ikrylova'I.; Malherbe, W.; Smit, N.J. First report of metazoan parasites from the cichlid Pseudocrenilabrus philander and the cyprinid Enteromius paludinosus in a South African Ramsar wetland. Afr. J. Aquat. Sci. 2016, 41, 499-503.

49. Whittington, R.J.; Chong, R. Global trade in ornamental fish from an Australian perspective: The case for revised import risk and analysis and management strategies. Prev. Vet. Med. 2007, 81, 92-116.

50. Yeh, L.S. On a new tapeworm Bothriocephaltu gowkongeñ̃s n. sp. (Cestada: Bothriocephalidae) from freshwater fish in China. Acta Zool. Sin. 1955, 7, 69-74.

51. Yera, H.; Kuchta, R.; Brabec, J.; Peyron, F.; Dupouy-Camet, J. First identification of eggs of the Asian fish tapeworm Bothriocephalus acheilognathi (Cestoda: Bothriocephalidea) in human stool. Parasitol. Int. 2013, 62, 268-271. 